\title{
INNOVATIVE METHODS AND TECHNIQUES IN THE EDUCATION SYSTEM
}

\author{
Boltayeva Moxichexra Jamshidovna
}

A Senior Lecturer At The Jizzakh Branch Of The National University Of Uzbekistan Named After Mirzo Ulugbek, Uzbekistan Fayzullayev Sherzod Bahodirovich

A Senior Lecturer At The Jizzakh Branch of The National University Of Uzbekistan Named After Mirzo Ulugbek, Uzbekistan

\section{ABSTRACT}

"Pedagogical system" Defining the role of innovative technologies in the development of education. Pedagogical substantiation of development and introduction of innovative methods in education. The role and application of methods in the education system. Intensive development and extensive development in the education system. Development and introduction of innovative methods in the modern education system. VF Shatalov "methodical". G.K.Selevko "methodology", S.N.Lisenkova "methodology".

KEYWORDS:- Innovation, technology, methodology, technical means of education, intensive development, extensive development.

\section{INTRODUCTION}

One of the greatest blessings of our independence is our quality education system. Any field is polished in the process of development. Education is no exception. In the age of globalization, the concepts of "innovation" and "innovative technology" are becoming an integral part of our lives. Innovative technology contributes to the development of a "pedagogical system" in education. Innovative technologies are reflected in the technology of methodologies in the pedagogical system. The pedagogical system is a very strong combination of elements. The structure of any pedagogical system today consists of the following interrelated elements:

- student;

- educational purpose;
- educational content;

- learning process;

- teachers (or TME - technical means of education);

Each component of this system can be divided into elements of any size. It should be noted that the pedagogical system is always a technology. It is on this basis that it can be easily distinguished from an arbitrary "set" of components of the pedagogical system.

Technology is the intrinsic quality of a system that determines its capabilities while adhering to strict organizational logic. However, even at the level of task evaluation, the technologist relies on certain processes and events. Certain processes are used as evidence of success, and the results of remarkable events are realized as new sources of cause and effect. The design of educational 
CURRENT RESEARCH JOURNAL OF PEDAGOGICS 2(11): 147-151,

November 2021 DOI: https://doi.org/10.37547/pedagogics-crjp-02-11-28

ISSN 2767-3278

(C)2021 Master Journals

Crossref do: 81 Google

Accepted 25th November, 2021 \& Published 30 ${ }^{\text {th }}$ November, 2021

technologies does not provide an "impossible" conclusion other than a methodological "generalization of experience". There are two main ways to improve the pedagogical system: intensive and extensive. Intensive development involves improving the pedagogical system at the expense of internal capabilities, and extensive development involves the involvement of additional forces - that is, at the expense of tools, equipment, technology.

In general, we should try to incorporate new theoretical approaches into innovative ideas in solving pedagogical problems based on new knowledge about the process of human development, high results obtained from specific practical technologies. The number of total and partially innovative projects on the relevance of the level of development of ideas in pedagogy, as well as the analysis of their application in pedagogical practice allowed them to be included in general pedagogical innovations.

1) Includes the system of pedagogical science and pedagogical practice, general ideas and practical technologies for the harmonization of the educational process, which are not new, but always up-to-date and self- provides itself.

2) A set of all theoretical principles and applied technologies of humanistic pedagogy.

3) The organization and management of pedagogical processes are based on a new ideological approach.

4) Technologies based on the application of new ideas and media, mass communications are innovative technologies.

The main directions of innovative structures in the pedagogical system: $\urcorner$

- unitary pedagogical system;

- education; pedagogical theory;

- teacher; students;
- pedagogical technology;

- content;

- forms, methods, tools;

- management;

- goals and results.

Innovative data on the depth, quality and new entries of substructures can be considered.

VF Shatalov developed and implemented the acceleration of teaching in education. He showed an undiscovered great application of traditional methods of teaching in the classroom. V.F. Shatalov's goals:

- building knowledge, skills and competencies;

- educating all children with any individual characteristics;

- Accelerate learning.

- Principles:

- repetition, mandatory step-by-step control, high level of difficulty, learning in large blocks, dynamic pattern of activity, behavioral support, and application of the intended basis of the line;

- $\quad$ person-centered approach;

- humanity;

- non-compulsory education;

- Conflict of learning situations, awareness of each student's achievements, correction (memorization);

- V.F. Features of the Shatalov method:

- materials are imported in large quantities;

- materials are placed in blocks;

- The study material is presented in the form of the main abstract.

As can be seen from the above, the basic abstract constitutes the visual scheme. VF Shatalov 
CURRENT RESEARCH JOURNAL OF PEDAGOGICS 2(11): 147-151,

November 2021 DOI: https://doi.org/10.37547/pedagogics-crjp-02-11-28

ISSN 2767-3278

(C)2021 Master Journals

Crossref doi) 81 Google

Accepted 25th November, 2021 \& Published 30 ${ }^{\text {th }}$ November, 2021

represents the basis of the child's actions, the way of external organization of internal thinking. The main signal is a cross-linked character (character, word, diagram, picture, etc.) that changes some meaning. A master's program is a system of basic cues in the form of a short conditional synopsis that consists of visual constructions used to understand a system of facts, concepts, and ideas as part of an interconnected approach to teaching materials. VF Shatalov's merits are that he developed a system of educational activities that ensures adequate and active participation in lessons. VFShatalov's methodology consists of 4 stages, which include a number of methods and methodological solutions: 1. Study of the theory in the lesson: a simple explanation on the board (with chalk, visual aids, OTV) poster - reexplanation. basic abstract; a brief description of the poster; individual work of students on abstracts, comprehensive strengthening of abstract blocks.

2. Independent work at home: basic program + textbook + parental support. Teaching students: read material from a book, remember what the teacher explained using an abstract; compare what you read with the synopsis; narration of textbooks using coding (coding-decoding); remembering the abstract as a basis for storytelling; process the abstract and compare it with the sample.

3. The first repetition is a comprehensive control of the mastery of the abstract: all students process the abstract in memory, the teacher checks them in advance, as well as "slowly" and asks in writing through the tape oral questioning starts. after work.

4. Oral description of the basic syllabus is the most important stage of external speech (oral) activity in the learning process, which takes place in various question-answer processes.

5. Second iteration-generalization and systematization: mutual control lessons; publish a list of pre-test questions;

Every rating, says V.F. Shatalov should, first and foremost, serve as a means of motivating the student. Both assessments evoke negative emotions and lead to conflict with the teacher and the science. Shatalov eliminates such conflicting situations. The system of educational activities developed by VF Shatalov was tested in schoolchildren, but its methodology went beyond the teaching of mathematics and became widespread not only in the teaching of natural sciences, but also in the humanities: language, history. GK Selevko describes pedagogical technology as a managed system with planned outcomes. The structure of the technological process is recommended in three main directions of information flow. In this structure, GK Selevko identifies three points of sale:

1. The main point is the movement of content, the transfer of information from the source (teacher) to the recipient (student) (transfer to the attention of students, management of educational activities, the acquisition of knowledge through the perception of students). infection). , assimilation and strengthening). Additional sources of information management books, hardware, computers, and independent perception (self-management process) by the reader - are important.

2. The point of influence of management. It includes planning (correcting strategic and tactical) and correcting basic psychological behaviors of learning data.

3. Information processing (feedback, monitoring, evaluation, additional information) from teacher to student.

Management of innovative teaching using the interpretation of the basic schemes of SN Lisenkova technology. The basis of this technology: 
CURRENT RESEARCH JOURNAL OF PEDAGOGICS 2(11): 147-151,

November 2021 DOI: https://doi.org/10.37547/pedagogics-crjp-02-11-28

ISSN 2767-3278

(C)2021 Master Journals

Crossref doi) 81 Google

Accepted 25th November, 2021 \& Published 30 ${ }^{\text {th }}$ November, 2021

- personal approach to collaborative pedagogy;

- mastery (success) - the most important condition for the development of children in the learning process;

- interest in the lesson: kindness, mutual assistance;

- warning about mistakes, but not working on mistakes;

- $\quad$ sequence of study material;

- The assignment is easy for each student and is given to them individually; - gradual transition to full independence;

- Teaching unfamiliar students through bilingual students.

The peculiarity of SN Lisenkova's method is that difficult topics are studied before the scheduled hours, not before. This is a promising preparation. Exploring prospective preparation is the beginning of a journey through challenging topics in the future. Generalization is the generalization of a topic based on specific knowledge.

The study of the material based on the method of SN Lisenkova is carried out in three stages:

1) To provide a small amount of knowledge to be acquired in the future;

2) Identify, name and apply new concepts;

3) Develop fluency in thinking and learning behaviors. Inge Unt, A.S. Graniskaya, V.D. In Shadrikov's research, individual teaching is defined as a form, a model of organization of the educational process.

Then:

- The teacher interacts with only one student;

- A student interacts only with teaching aids (books, computers, etc.). In individual teaching, the content, methods and image of the activity are adapted to the characteristics of the student.

- When it comes to personal approach:

- is a principle of pedagogy, according to which the teacher interacts with individual students on an individual model, taking into account the individual characteristics of students in the educational process, and based on individual characteristics;

- take into account the individual characteristics of students in the learning process;

- It is understood that not only the development of all students, but also the creation of psychological and pedagogical measures for the individual development of each student. Individualized teaching:

- The organization of the educational process, in which the choice of teaching methods and images is associated with the individual characteristics of the student;

- Various educational-methodical, psychological-pedagogical and organizational-administrative measures that provide an individual approach.

- The individualization of teaching is based on the following authoring technologies:

- Inge Unt's technology of individualization of teaching;

- A.S. Gransikaya Flexible Learning Technology;

- VD Shadrikov's technology of teaching on the basis of individual plan. Inge Unt's basic concept in the technology of individualization of teaching is that an important form of individualization of teaching in the current context is the independent work of students at school and 
CURRENT RESEARCH JOURNAL OF PEDAGOGICS 2(11): 147-151,

November 2021 DOI: https://doi.org/10.37547/pedagogics-crjp-02-11-28

ISSN 2767-3278

(C)2021 Master Journals

Crossref do: 81 Google

Accepted 25th November, 2021 \& Published 30 ${ }^{\text {th }}$ November, 2021

at home. Inge Unt understands its content and methodology as individual learning tasks for independent work, workbooks published on the basis of individualized independent work manual, adapted to the current educational literature.

A.S. As Graniskaya points out, it is possible to organize a flexible system of teaching in the classroom, where the teacher spends 60-80 percent of his time working individually with students. The peculiarity of the method of AS Graniskaya is that it organizes the lesson on the basis of a certain unusual device:

- Part One - Teaching Everyone;

- The second part is two parallel processes: independent work of students and individual work of the teacher with individual students, i.e. the use of generalized schemes, work as a teacher on duty, flexible multidisciplinary tasks and so on.

In the current era of globalization, it is important to identify advanced innovations in education, to organize their funds, to test them, to apply them in pedagogical practice, to develop scientific conclusions and to create a system of their implementation. In this regard, a number of research and innovative methodological support is needed. It is necessary to strengthen teaching in education with new innovative technologies and try to increase its overall effectiveness through a systematic approach. In this approach, innovation is not an imaginary "external" dimension, but a profound demand and knowledge of the system, a conscious change.

\section{ReFERENCES}

1. Yuldashev J. New pedagogical technology: directions, problems, solutions. Public Education, 1999, No. 4, pp. 4-11.

2. Mahmudov M. The system of didactic design of educational materials. "Pedagogical skills", 2002, issue 3, pages 3-11.

3. Mahmudov M. Learning Outcomes. // «Pedagogical skills», 2003, issue 1, pages 810.

4. Nishonova Z.T. High school psychology. Tashkent, 2003. 13. Scientific bases of application of pedagogical technologies in educational process of higher pedagogical educational institutions. Materials of the Republican scientific-methodical conference. - T .: TDPU named after Nizami, 2000. 111 p.

5. M.J.Boltaeva,O.Kh.Ortikov.(2020).Views of eastern thinkers on the development of intellectual abilities in the scientific heritage. Academicia An International Multidisciplinary Research Journal Vol. 11 Issue 1, January 2021 211-214.

6. K. B. Murotmusaev, M.Z. Dzhelyalov, M.J. Boltaeva. Psychological Aspects Of Human Health And The Power Of Love. The American Journal of Applied sciences. February 25, 2021 p 73-77.

7. B.U.Nasirov, M.J.Boltaeva. "Genesis And Transformation of The Public Catering System In Uzbekistan During The Soviet Period" Turkish Online Journal of Qualitative Inquiry (TOJQI) Volume 12, Issue 7, July 2021. P 5834 - 5841.

8. M.J.Boltaeva,O.Kh.Ortikov. Features of the scientific heritage of eastern thinkers about the attitude of parents to the child. Society and innovations. Special Issue - 2 (2021) p 469-474. 